\title{
CARIES OVERVIEW IN PRIMARY SCHOOL STUDENTS ASSISTED BY DENTAL SCHOOL PROGRAM CIMAHI PUBLIC HEALTH CENTRE (GAMBARAN PENYAKIT KARIES MURID SEKOLAH DASAR BINAAN USAHA KESEHATAN GIGI SEKOLAH PUSKESMAS DI KOTA CIMAHI)
}

Badi Soerachman $^{1 *}$, Syarif Soewondo ${ }^{2}$, Syifa Khairunnisa Mauluddin ${ }^{1}$ ${ }^{1}$ Department of Conservative Dentistry Faculty of Dentistry Universitas Jenderal Achmad Yani, Cimahi, Indonesia ${ }^{2}$ Department of Oral Public Health Faculty of Dentistry Universitas Jenderal Achmad Yani, Cimahi, Indonesia

*Corresponding author Badi.soerachman@,lecture.unjani.ac.id

\section{Doi:}

10.54052/jhds.v1n3.p299308

Article History Received:22/11/2021 Accepted: 20/12/2021

\begin{abstract}
Public Health Centre/Pusat Kesehatan Masyarakat (Puskesmas) in Indonesia planned dental and oral health efforts aimed at specific groups continuously in the promotive, preventive, and curative fields is through the Dental School Program/Usaha Kesehatan Gigi Sekolah (UKGS) program. UKGS is divided into three stages consisting of UKGS stage 1 (minimal package), stage 2 (standard package), and stage 3 (optimal package). This study aimed to examine the three stages of UKGS held by the Public Health Centre in the case of caries disease that occurs in primary school students in Cimahi. This research was a descriptive study by conducting the DMFT index in 12-year-old primary school students. Primary school selection was taken by random cluster sampling, and the number of participants was 87 students. The number of samples needed for this study used the determination of total sampling. It was obtained in UKGS primary school stages 1 (41 students), stage 2 (33 students), and stage 3 (13 students), and subjects were taken based on inclusion and exclusion criteria. The study results show that the DMFT index for
\end{abstract}


primary school students assisted by UKGS stage 1 at the level of 5,14, UKGS stage 2 at the level of 3,06, and UKGS stage 3 at the level of 1,23. There are also DMFT score levels between male and female students; scores of 3,5 (male) and 2,6 (female).

Keywords: caries; DMFT index

\section{ABSTRAK}

Pusat kesehatan masyarakat (Puskesmas) di Indonesia melaksanakan upaya kesehatan gigi dan mulut yang terencana dan ditujukan kepada kelompok tertentu yang diselenggarakan secara berkesinambungan dalam bidang promotif, preventif, dan kuratif yaitu salah satunya melalui program Usaha Kesehatan Gigi Sekolah (UKGS). UKGS terbagi menjadi tiga tahapan yang terdiri dari UKGS tahap 1 (paket minimal), tahap 2 (paket standar), dan tahap 3 (paket optimal). Tujuan dari penelitian ini untuk mengetahui gambaran penyakit karies yang terjadi pada murid sekolah dasar binaan UKGS puskesmas tahap 1, 2, dan 3 di Kota Cimahi. Penelitian ini merupakan penelitian deskriptif dengan melakukan pemeriksaan indeks DMFT pada murid sekolah dasar usia 12 tahun. Pemilihan SD/MI diambil secara cluster random sampling dan jumlah seluruh sampel yang didapatkan adalah 87 murid. Jumlah sampel yang diperlukan untuk penelitian ini menggunakan penentuan total sampling dan didapatkan pada SD/MI UKGS tahap 1 (41 murid), tahap 2 (33 murid), dan tahap 3 (13 murid) dan subjek diambil berdasarkan kriteria inklusi dan eksklusi. Hasil penelitian ini menggambarkan indeks DMFT pada murid sekolah dasar binaan UKGS tahap 1 yaitu 5,14; lalu pada UKGS tahap 2 yaitu 3,06; dan pada UKGS tahap 3 yaitu 1,23. Terdapat juga gambaran indeks DMFT antara murid laki-laki dan perempuan yaitu dengan nilai indeks DMFT 3,5 (laki-laki) dan 2,6 (perempuan).

Kata kunci: indeks DMFT; karies 


\section{INTRODUCTION}

Dental health is very crucial, especially for children's development. One dental health problem often found in children is dental caries. The economic impact of dental caries is weakening the community's productivity. If those who experience are children, it will delay their growth. As a result, it can reduce the level of intelligence of children, which in the long term, it will have an impact on the community's quality of life. WHO has assigned the age of 12 years old as the global monitoring age for caries because when children are 12 years old, the permanent teeth have already been completed except for the third molar teeth. The 2018 Riskesdas stated that the caries prevalence of 12 years old in Indonesia was $72 \%$ and had a DMFT index in the low category, with an index value of 1.9. ${ }^{1-3}$

Maintenance of dental and oral hygiene is one of the efforts to prevent caries. Boys and girls have different characteristics in maintaining their dental and oral hygiene. Girls usually tend to pay more attention to aesthetic aspects, such as beauty, hygiene, and personal appearance; therefore, they pay more attention to their dental and oral health, whereas boys pay less attention to the beauty and hygiene of their dental and said. ${ }^{4}$

The child's environment influences the risk of caries. One of the environments that play a role in developing children's behavior in nurturing dental and oral health is the school environment through the implementation of the Usaha Kesehatan Gigi Sekolah (UKGS). UKGS is one of the dental and oral health service programs at the public health center or Pusat Kesehatan Masyarakat (Puskesmas). It is under the Usaha Kesehatan Sekolah (UKS). UKGS is divided into three stages consisting of UKGS stage 1 (minimum package), stage 2 (standard package), and stage 3 (optimal package). UKGS stage 1 has three activities: training on dental and oral health for small doctors and teachers handling the UKGS program, providing dental and oral health education according to the curriculum and doing toothbrushes together. Then the UKGS stage 2 has seven activities, 3 of which have the same activities as UKGS stage 1. Still, at stage 2, the emergency treatment has been implemented to relieve tooth pain for some students, dental and oral health screening, and make referrals to the Puskesmas. All the activities in stage 2 are also carried out in stage 3 , but what made them different is that UKGS stage 3 has already carried out basic medical and dental services on demand (care on demand). The UKGS program has been running since 1951, but the dental health status of children aged 12 years old 
is still not satisfying. ${ }^{5,6}$

All Puskesmas in Cimahi have implemented UKGS stages 1, 2, and 3. Out of 149 primary schools or Sekolah Dasar/Madrasah Ibtidaiyah (SD/MI) in Cimahi, 21 schools assisted for UKGS stage 1, 48 schools assisted for UKGS for stage 2, and 80 schools assisted for UKGS stage 3 . Every stage of UKGS has different activities. Based on data from the report of 2018 UKGS services in Cimahi, from 300.921 students of SD/MI who assisted for UKGS, there were only 23.757 students who received checkups, and 9.979 students were found to need treatment. ${ }^{7,8}$

Based on the reported data, no data shows and explains the overview of caries disease in UKGS-assisted primary school students from every stage. Research on the overview of caries disease in primary school students assisted by UKGS stages 1, 2 , and 3 has never been conducted in Cimahi. Accordingly, the writers are encouraged to research the overview of caries disease in primary school students assisted by UKGS Puskesmas stages 1, 2, and 3.

\section{METHOD}

All Puskesmas in Cimahi have implemented UKGS stages 1, 2, and 3. Out of 149 primary schools or Sekolah Dasar/Madrasah Ibtidaiyah (SD/MI) in
Cimahi, 21 schools assisted for UKGS stage 1, 48 schools assisted for UKGS for stage 2, and 80 schools assisted for UKGS stage 3. Every stage of UKGS has different activities. Based on data from the report of 2018 UKGS services in Cimahi, from 300.921 students of SD/MI who assisted for UKGS, there were only 23.757 students who received checkups, and 9.979 students were found to need treatment. ${ }^{7,8}$

Based on the reported data, no data shows and explains the overview of caries disease in UKGS-assisted primary school students from every stage. Research on the overview of caries disease in primary school students assisted by UKGS stages 1 , 2 , and 3 has never been conducted in Cimahi. Accordingly, the writers are encouraged to research the overview of caries disease in primary school students assisted by UKGS Puskesmas stages 1, 2, and 3 .

Measurement method was carried out by checking all permanent teeth except the third molar. According to the score criteria of WHO, namely 0.0-1.1 include very low criteria, 1.2-2.6 include low criteria, 2.7-4.4 include moderate criteria, 4.6-6.5 include high criteria, $>6.6$ include very high criteria. Data analysis conducted in this study was descriptive analysis which aims to describe or figure out the data has been collected. The data was then presented in the form of 
tables and narratives.

\section{RESULT}

The research result of description of Caries in Primary School Students Assisted by UGKS Puskesmas in children stage 1,2, 3 can be seen in the overview of dental caries based on the number of teeth $\mathrm{D}, \mathrm{M}$, and $\mathrm{F}$ in Table 1.

Table 1. Overview of dental caries based on the number of teeth $\mathrm{D}, \mathrm{M}$, and F

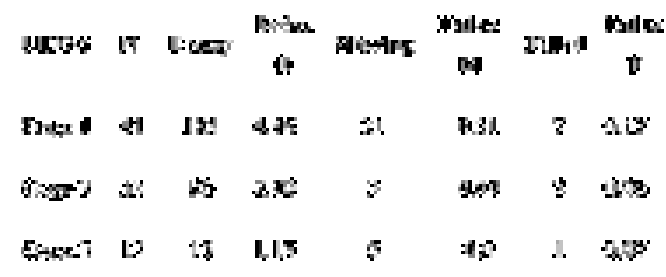

Based on Table 1, it can be seen that most of the dental caries overviews were found in the UKGS stage 1, namely, from the total of 41 examined students, 183 dental caries were found with a decay index value of 4.46 (high category). It can also be seen that missing teeth overview due to caries is more commonly found in $\mathrm{SD} / \mathrm{MI}$ assisted by UKGS stage 1, with the missing index value still in the very low category, namely 0.51 . Moreover, the overview of the filled index at UKGS stage 1 is 0.17 , UKGS stage 2 is 0.06 , and UKGS stage 3 is 0.07 , and all of these filled indices are still in the very low category.

Overview of caries based on DMFT index and prevalence can be seen in Table 2.

Table 2. Overview of caries based on DMFT index and prevalence

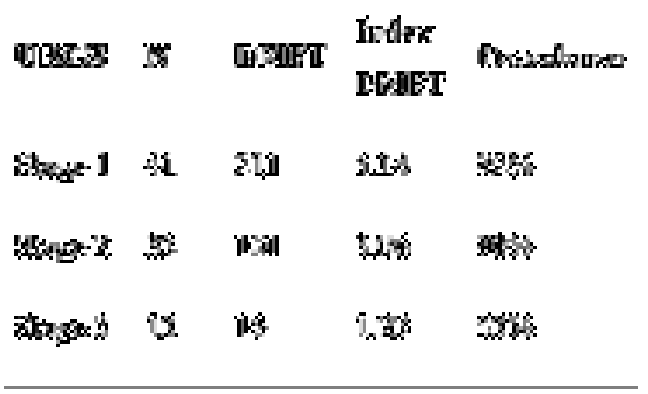

Table 2 shows the SD/MI assisted by UKGS stage 1 has a DMFT index in the high category, namely 5.14. The UKGS stage 2 has an overview of the DMFT index in the medium category, namely 3.06, and UKGS stage 3 has an overview of the DMFT index in the low category, namely 1.23. The results showed that the prevalence of caries in the UKGS stage 1 was $92 \%$ and the UKGS stage 2 was $90 \%$, and this illustrates that almost all children in this study suffer from dental caries. Meanwhile, UKGS stage 3 describes a lower prevalence than UKGS stage 1 and stage 2, 53\%.

Results of caries examination management data by gender can be seen in Table 3. 
Table 3. Results of examination of the number of teeth $\mathrm{D}, \mathrm{M}$, and $\mathrm{F}$ based on gender

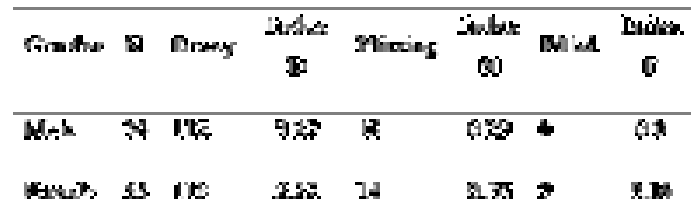

Table 3 shows that dental caries was found in many boys, with a decay index of 3.29 (medium category), while girls have a decay index of 2.22 (low category). Meanwhile, missing teeth in boys and girls have an index value overview in the same category, which is a very low category. But the overview of teeth that have been restored was only found in girls, namely with an index value-filled 0.16 (very low category).

Results of index DMFT and caries prevalence examination based on gender can be seen in Table 4.

Table 4. Result of Index DMFT and caries prevalence examination based on gender

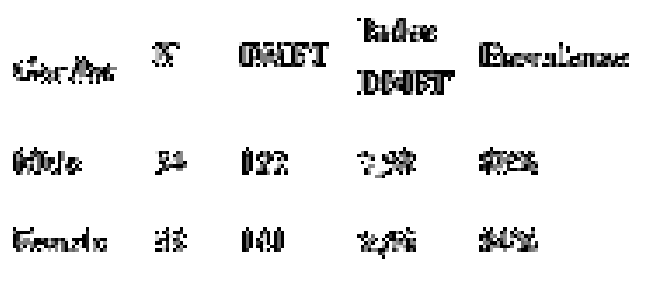

Table 4.6 shows the overview that male students have a DMFT index of 3.58 (medium category) and female students have a DMFT index of 2.66 (low category). The prevalence in boys was $88 \%$, and the prevalence of girls was $84 \%$, it illustrates that boys experienced more caries in the study.

\section{DISCUSSION}

Puskesmas is a health service facility that organizes public health efforts and firstlevel individual health efforts. The Puskesmas carries out planned dental and oral health efforts aimed at certain groups, which are carried out continuously in the promotive, preventive, and curative fields, one of which is through the School Dental program/UKGS. UKGS consists of 3 stages, namely stage 1 (minimum package), stage 2 (standard package), stage 3 (optimal package). WHO set the age of 12 years as the global monitoring age for caries. The pain caused by caries can worsen the overall health of both boys and girls $72 \%$, and the DMFT index for 12-year-olds is still in the low category, namely 1.9. The UKGS stages have different implementations so that they affect the picture of caries disease in each elementary school and the equivalent by using the DMFT index measurement. ${ }^{2,3}$

The results of basic health research in 2018 the prevalence of caries in children aged 12 years is still Based on the research conducted by Notohartojo in 2013. The 
filled values were smaller from this research and the missing values. Respondents in this study are still in the young age category and may not know the importance of maintaining dental and oral health. In contrast, one of the goals of Oral Health 2020 that has been agreed upon by WHO, FDI, and IADR for dental caries in Indonesia is to reduce $\mathrm{D}$ (decay) component at the age of 12 years. Therefore, the implementation of UKGS needs to be improved. $^{9}$

UKGS implementation influenced the status of caries experience. It is following a study conducted by Natalina (2009). In contrast to the research results shown by Amaniah (2009), which stated that there was no significant relationship between UKGS implementation activities and the DMFT index. ${ }^{10}$

Based on the findings in the field, only schools assisted by UKGS stage 3 carry out mass toothbrushing activities every day. In the UKGS Guidelines issued by the Directorate General of Health Efforts at the Ministry of Health of the Republic of Indonesia, it was stated that one of the UKGS activities is to carry out mass toothbrushing activities every day. It may be one of the factors causing the low DMFT index at stage 3 UKGS.

In contrast to the results of research conducted by Hansen (2014) in
Tumangtang Village 1, it was stated that boys aged 11-12 years have a lower decay component than girls. According to Hansen, this was due to the time factor of the eruption of girls' teeth that occur faster, resulting in more exposure to cariogenic foods. ${ }^{11}$

This result contrasts with Mbipa et al. (2019). It was stated in their study that the DMFT index of boys belonged to a very low category and in girls belonged to the medium category. ${ }^{12}$

This study has similar results with Rara Warih in 2015 that the DMFT index in male students showed higher grades than female students. According to research conducted by Wowor 2013, in his research stated that the health behavior of girls' dental and oral is better than boys. Girls are better at behaving in maintaining the health of their mouths than boys, this is because girls are more concerned and have a high awareness of aesthetics and maintenance of dental health so that they will be more diligent to brush their teeth. ${ }^{13,14}$

Health workers and education personnel in Cimahi are expected to improve the implementation of UKGS regularly and continuously and to be able to increase promotive and preventive efforts for primary school students, especially those who are aged 12 years old in the field of dental and oral health. Dental and oral 
health services for elementary school students include dental health education, which consists of communication, education, information, and early detection and treatment. It is a basic need to fulfill dental health services for school children. The long-term target in 2020 of the UKGS program at Puskesmas is the caries-free rate at the age of 6 years with mixed teeth (primary teeth and permanent teeth) of more than $50 \%$, the caries-free rate in grade 6 elementary school students more than $70 \%$, Decay Missing Filled-Teeth (DMF-T) at the age of 12 years is less than 1 , Performance Treatment Index (PTI) is equal to $50 \%$, and the dentally fit rate in grade 6 elementary school students is more than $85 \%{ }^{15,16}$ it is hoped that it can be a reference for developing another research on UKGS.

\section{CONCLUSION}

Based on the results and discussions of the research conducted, it could be concluded that the overview of DMFT index UKGS stage 1 includes high criteria, UKGS level 2 has medium criteria, and UKGS level 3 includes low criteria. The summary of the DMFT index for male students included in the medium criteria and for female students included in low criteria.

\section{CONFLICT OF INTEREST}

We declare that there is no conflict of interest in the scientific articles.

\section{ACKNOWLEDGEMENT}

This research data was supported by Public Health Centre or Pusat Kesehatan Masyarakat (Puskesmas) Cimahi and MI Ar-Riyadl, SDN Melong Asih 5, dan MI Nurul Iman Cimahi Indonesia.

\section{REFERENCES}

1. Sariningsih E. Merawat gigi anak sejak usia dini. Jakarta: Gramedia. 2012: 314-315.

2. Kementrian Kesehatan RI. Laporan nasional riskesdas. Kemenkes RI. Jakarta. 2018.

3. WHO. Oral health surveys basic methods. $5^{\text {th }}$ ed. Geneva: WHO Document Production Service. 2013: 14.

4. Mbipa MM, Pay MN, Manu AA, Nubatonis MO. Perbedaan tingkat kejadian karies gigi (DMF-T) antara laki-laki dan perempuan usia 12-14 tahun. Dental Therapist Journal. 2019; 1: 25-27.

5. A'yun Q, Hendrartini J, Separtinah A. Pengaruh keadaan rongga mulut anak, perilaku ibu, dan lingkungan terhadap resiko karies pada anak. MKGI 2016; 2: 87. 6. Kementrian Kesehatan RI. Pedoman usaha kesehatan gigi sekolah (UKGS). Kemenkes RI. Jakarta. 2012. 
7. Dinas Kesehatan Kota Cimahi. Profil Kesehatan. Dinkes Kota Cimahi. Cimahi. 2018.

8. Dinas Kesehatan Kota Cimahi. Daftar tahapan UKGS. Dinkes Kota Cimahi. Cimahi. 2019.

9. Notohartojo IT, Magdarina DA. Penilaian indeks DMDT anak usia 12 tahun oleh dokter gigi dan bukan dokter gigi di kabupaten Ketapang provinsi Kalimantan Barat. Media Litbangkes. 2013: 23.

10. Hutabarat N. Peran petugas kesehatan, guru, dan orang tua dalam pelaksanaan UKGS dengan tindakan pemeliharaan kesehatan gigi dan mulut murid sekolah dasar di Kota Medan. Medan: Universitas Sumatera Utara. 2009. 11. Wala HC, Wicaksono DA, Tambunan E. Gambaran status karies gigi anak usia 11-12 tahun pada keluarga pemegang jamkesmas di kelurahan tumatangtang 1 kecamatan tomohon selatan. Manado: Fakultas kedokteran Univesitas Sam Ratulangi. 2014.

12. Mbipa MM, Pay MN, Manu AA, Nubatonis MO. Perbedaan tingkat kejadian karies gigi (DMF-T) antara laki-laki dan perempuan usia 12-14 tahun. Dental Therapist Journal 2019; 1: 25-27.

13. Gayatri RW, Mardianto. Gambaran status karies gigi anak sekolah dasar kota Malang. Fakultas Ilmu Keolahragaan: Universitas Negeri Malang. 2015.
14. Wowor VE. Hubungan antara status kebersihan mulut dengan karies siswa sekolah menengah atas 1 Manado. Manado: Program Studi kedokteran Gigi Universitas Sam ratulangi. 2013.

15. Peraturan pemerintah kesehatan RI. Standar pelayanan minimal bidang kesehatan tingkat kabupaten/kota. Permenkes RI: 2008.

16. Kementerian kesehatan RI. Rencana program pelayanan kesehatan gigi dan mulut. Kemenkes RI. Jakarta. 2012: 23. 